Volume 1 Issue 1, January-June 2020: pp.27-38.

Faculty of Law, Universitas Lampung, Bandar Lampung, Indonesia.

http://jurnal.fh.unila.ac.id/index.php/ip

P-ISSN: 2723-2638

E-ISSN: $2745-9314$

\title{
Perlindungan Hukum Terhadap Anak Sebagai Saksi dalam Perkara Tindak Pidana Pemerkosaan
}

\author{
Legal Protection of Children as Witnesses in the Crime of Rape
}

\author{
Erna Dewi \\ ernadewi00@yahoo.co.id \\ Fakultas Hukum Universitas Lampung \\ Volanda Azis Saleh \\ volandaazissaleh@gmail.com \\ Fakultas Hukum Universitas Lampung
}

Submitted: Mar 3, 2020; Reviewed: Mar 17, 2020; Accepted: Apr 6, 2020

\begin{tabular}{|c|c|}
\hline Info Artikel & Abstrak \\
\hline $\begin{array}{l}\text { Kata Kunci: Perlindungan; Saksi } \\
\text { Korban; Pemerkosaan. } \\
\text { Keywords: Protection; Victim Witness; } \\
\text { Rape. }\end{array}$ & $\begin{array}{l}\text { Perlindungan hukum bagi saksi korban dalam } \\
\text { persidangan menjadi isu penting yang harus } \\
\text { disikapi. Dalam pelaksanaan dilapangan tidak } \\
\text { sedikit saksi korban khawatir memberikan } \\
\text { kesaksiannya di persidangan karena tidak ada }\end{array}$ \\
\hline $\begin{array}{l}\text { DOI: } \\
\text { https://doi.org/10.25041/ip.v1i1.2042 }\end{array}$ & $\begin{array}{l}\text { kepastian hukum dalam bentuk perlindungan di } \\
\text { persidangan. Penellitian ini akan fokus pada } \\
\text { dua permasalahan hukum yaitu menganalisa } \\
\text { perlindungan hukum terhadap anak sebagai } \\
\text { saksi dalam perkara tindak pidana } \\
\text { pemerkosaan dan mengetahui terjadi hambatan } \\
\text { terhadap perlindungan anak sebagai saksi } \\
\text { dalam perkara tindak pidana pemerkosaan. } \\
\text { Penelitian ini menggunakan pendekatan } \\
\text { Yuridis Normatif dilakukan terhadap hal-hal } \\
\text { yang bersifat teoritis asas-asas hukum, } \\
\text { Berdasarkan hasil penelitian, bahwa } \\
\text { perlindungan hukum terhadap anak sebagai } \\
\text { saksi dalam perkara tindak pidana } \\
\text { pemerkosaan berupa persetujuan dari hakim }\end{array}$ \\
\hline
\end{tabular}


terhadap saksi korban anak dapat memberikan kesaksiannya dengan tanpa harus hadir secara langsung saat pemeriksaan perkaranya dipengadilan, dengan menggunakan sarana telekomunikasi berupa video call atapun mengakui keterangan saksi tertulis kemudian dibacakan dipersidangan. Selanjutnya faktor yang menjadi hambatan terhadap perlindungan anak sebagai saksi dalam perkara tindak pidana pemerkosaan yaitu, Lembaga Perlindungan Saksi Korban (LPSK) belum dibentuk di masing-masing daerah, belum diaturnya bentuk perlindungan saksi di dalam Kitab UndangUndang Hukum Acara Pidana (KUHAP) serta belum efektifnya kerjasama antara LPSK dengan instansi penegak hukum. Saran yang dapat disampaikan yaitu sebaiknya penegak hukum harus memberikan perlindungan kepada saksi korban dari ancaman dan intimidasi. Sebaiknya pemerintah segera memperbaharui undang-undang Perlindungan Anak dan undang-undang Perlindungan saksi Korban tentang bentuk perlindungan terhadap saksi anak sebagai koban yang dapat memberikan keterangannya dengan menggunakan sarana telekomunikasi berupa video call atapun mengakui keterangan saksi tertulis kemudian dibacakan dipersidangan.

\section{Abstract}

Legal protection for victim witnesses in the trial becomes an important issue that must be addressed. because in the field implementation there were not a few victims witnesses worried about giving their testimony at the trial because there was no legal certainty in the form of protection in the trial. The problem in writing this thesis is how is the legal protection of children as witnesses in cases of rape crimes? Why are there obstacles to the protection of children as witnesses in cases of rape crimes? This study uses a juridical normative and empirical approach. Normative research is done on things that are theoretical principles of law, while the empirical approach is done to study the law in fact in the field. Based on the results of the study, the legal protection of children who are witnesses in criminal cases against children who are 
victims in court cases can give their testimony without having tobe present when examining their cases in court, by using means related to video call or helping to uncover question that arises read out in court and Factors occur obstacles to the protection of children as witnesses in cases of first rape crimes, Factors of Witness and Victim Protection Agency that do not have representatives in the area and lack of socialization, Second Unregulated Form of Witness Protection in the Criminal Procedure Code so that witness protection does not get legal certainty. Third, the Cooperation between Witness and Victim Protection Institutions has not been effective with Law Enforcement Agencies. The suggestions that can be conveyed in this study should law enforcement should provide optimal protection to victims' witnesses until the threat and intimidation is completed on the victim. The government should immediately renew the Child Protection. Act and the Victim witness Protection Act concerning the form of protection for child witnesses as a victim who can provide his statement using telecommunications facilities in the form of video calls or acknowledge written witness statements and then read out in court.

\section{A. Pendahuluan}

Perlindungan hukum terhadap korban kejahatan sangat penting karena telah menjadi isu nasional, tak hanya itu perlindungan hukum tersebut sudah menjadi isu internasional. Oleh karena itu, masalah ini harus mendapat perhatian yang serius. Hal ini dapat dilihat dari dibentuknya Declaration of Basic Principles of Justice for Victims of Crime and Abuse Power oleh Perserikatan Bangsa-Bangsa (PBB), Sebagai hasil dari The Seventh United Nation Conggres on the Prevention of Crime and The Treatment of Offenders, yang berlangsung di Milan, Italia, September 1985. Dalam salah satu rekomendasinya disebutkan: "Offenders or third parties responsible for their behavior should, where appropriate, make fair restitution to victims, their families or dependants. Such restitution should include the return of property or payment for the harm or loss suffered, reimbursement of expenses incurred as a result of the victimization, the provision of services and the restoration of the rights."

Pada dasarnya hukum adalah pencerminan dari HAM, sehingga hukum itu mengandung keadilan atau tidak akan ditentukan oleh Hak Asasi Manusia yang terkandung dan juga diatur atau dijamin dalam hukum tersebut. Hukum tidak akan lagi dilihat sebagai cerminan dari kekuasaan semata-mata, namun juga harus mencerminkan perlindungan terhadap hak-hak 
para warga negara. ${ }^{1}$ Pelecehan seksual menjadi masalah yang sering terjadi di Indonesia, masalah ini menarik perhatian dari sekian banyak kasus yang terus terjadi. Terutama pada akhir-akhir ini kasus maraknya pelecehan seksual dengan kasus pemerkosaan terhadap remaja di Indonesia. ${ }^{2}$

Deklarasi di Milan pada Tahun 1985, menyatakan perlindungan hukum tidak hanya tertuju kepada korban kejahatan (victim of crime) semata, melainkan juga perlindungan pada korban karena adanya penyalahgunaan kekuasaan (abuse of power). ${ }^{3}$ Di Indonesia, berbicara mengenai konteks perlindungan pada korban kejahatan juga harus mendapatkan perhatian yang serius. Hal ini segera direspon oleh pemerintah dengan cara mengesahkan Undangundang Nomor 13 Tahun 2006 mengenai Perlindungan Saksi dan Korban. ${ }^{4}$ Namun, undangundang tersebut dianggap mempunyai beberapa kelemahan dalam beberapa substansinya, sehingga perlu dilakukan perubahan terhadap undang-undang tersebut. Kemudian oleh Pemerintah diterbitkan Undang-undang Nomor 31 Tahun 2014 yang merupakan Perubahan atas Undang-Undang Nomor 13 Tahun 2006 mengenai Perlindungan Saksi dan Korban yang disahkan oleh Pemerintah dan diundangkan untuk memperbaiki kelemahan pada UndangUndang Nomor 13 Tahun 2006 mengenai Perlindungan Saksi dan Korban, yang sebelumnya diberlakukan Peraturan Pemerintah Nomor 2 Tahun 2002 yang mengatur tentang Perlindungan terhadap Saksi dan Korban pada Pelanggaran Hak Asasi Manusia Berat. ${ }^{5}$

Berkenaan dengan perlindungan hukum terhadap anak, negara memberikan perhatian serius dengan mengesahkan Undang-Undang Nomor 35 Tahun 2014 yang merupakan Perubahan atas Undang-Undang Nomor 23 Tahun 2002 mengenai Perlindungan Anak, dalam upaya pemberian perlindungan hukum yang diharapkan dapat diberikan dasar hukum yang tegas dalam upaya perlindungan hukum terhadap berbagai tindak pidana yang dialami oleh anank. ${ }^{6}$ Pada dasarnya menyelenggarakan sistem keadilan pidana (Criminal Justice Sistem) maka pidana menempati satu posisi sentral. Hal ini disebabkan karena putusan didalam pemidanaan akan mempunyai konsekuensi yang luas, lebih-lebih apabila putusan pidana tersebut dianggap tidak tepat, maka akan menimbulkan reaksi yang "kontroversial", sebab kebenaran di dalam hal ini sifatnya adalah relatif tergantung dari mana kita memandangnya. ${ }^{7}$ Fenomena ini memang banyak terjadi khususnya bagi korban pemerkosaan yang jiwanya terancam baik psiskis maupun fisiknya keadaan trauma yang membekas dalam hatinya tidak akan mungkin secara maksimal memberikan keterangan apalagi dalam sebuah persidangan yang mana saksi korban akan berhadapan dan bertatap muka dengan pelaku keadaan tersebut justru membuat mental korban drop. Penulis melihat dalam hal ini pemerintah harus bertindak tegas dan merevisi Undang-Undang Nomor 8 Tahun 1981 tentang KUHAP karena tidak terdapat substansi perlindungan mengenai saksi korban kekerasan, pelecehan, dan eksploitasi

\footnotetext{
${ }^{1}$ Eka Intan et al., "Begal Anak; Pemenuhan Hak Dan Lembaga Pembinaan Khusus Anak Kelas Ii A Bandar Lampung Fulfillment Of The Rights Of The Child In The Class Ii Special Child Coaching Institution In Bandar Lampung," Cepalo 2, no. 2 (September 12, 2018): 45-84, https://doi.org/10.25041/cepalo.v2no2.1764. hlm 76.

${ }^{2}$ Meita Agustin Nurdiana, "Tindak Pidana Pemerkosaan: Realitas Kasus Dan Penegakan Hukumnya Di Indonesia”, Jurnal Fakultas Hukum Universitas Negeri Semarang (UNNES). Vol. 3. No. 1 (2019).

${ }^{3}$ Didik M Arif Mansur, Elisatris Gultom, Urgensi Perlindungan Korban Kejahatan Antara Norma dan Realita, Jakarta, Rajawali Pers, 2006 hlm. 23.

${ }^{4}$ Mutiara Nastya Rizky, Risma Intan Fitriani, Fatma Ayu Husnasari, Muhammad Wahyu Sudibiyo dan Firmansyah Maulana, "Perlindungan Hukum Terhadap Anak Korban Eksploitasi Seksual Komersial Melalui Media Sosial", Jurnal Media Iuris Vol. 2 No. 2, Juni 2019. hlm. 208.

5 Haris Budiman dan Gios Adhyaksa, "Implementasi Penerapan Undang-Undang Nomor 13 Tahun 2006 Tentang Perlindungan Saksi Dan Korban (Studi Di Polres Kuningan)," Jurnal Ilmu Hukum Unifikasi Develop Education and Legal Reseacrh." Vol. 2 No. 1 Januari (2015). Hlm . 56.

${ }^{6}$ Silviana Anggraeni Putri, Nur Rochaeti dan Budhi Wisaksono, "Perlindungan Hukum Bagi Anak Korban Tindak Pidana Perdagangan Manusia Berdasarkan Undang-undang Nomor 35 Tahun 2014 yang merupakan Perubahan atas Undang-undang Nomor 23 Tahun 2002 mengenai Perlindungan Anak," Diponegoro Law Journal. Vol. 6. No. 1 (2017).

${ }^{7}$ Sabar Slamet, Politik Hukum Pidana Dalam Kejahatan Perkosaan, Jurnal Yustisia Fakultas Hukum Universitas Sebelas Maret, Vol. 4. No. 2 ( 2017)
} 
seksual yang merupakan salah satu bentuk kejahatan kekerasan, bukan hanya menimpa perempuan dewasa, namun juga perempuan yang tergolong di bawah umur (anak-anak). Kejahatan kekerasan seksual ini juga tidak hanya berlangsung di lingkungan perusahaan, perkantoran, atau ditempat-tempat tertentu yang memberikan peluang manusia berlainan jenis dapat saling berkomunikasi, namun juga dapat terjadi di lingkungan keluarga. ${ }^{8}$

Maraknya kejahatan dapat kita lihat pada kasus Perkara Nomor: 175/Pid.Sus/2018/PN Kot. Dalam perkara tersebut anak yang menjadi korban tindak pidana pemerkosaan di dalam persidangan mengalami ketakutan untuk memberikan keterangannya, karena di intimidasi melalui penglihatan mata terdakwa kepada saksi anak tersebut, selain itu anak tersebut trauma dengan adanya terdakwa, tetapi akhirnya anak tersebut tetap jadi saksi. Hal tersebut jelas akan berdampak tidak maksimal dalam memberikan kesaksiannya.

Contoh kasus juga dialami oleh oleh putri kandung terdakwa, kasus ayah yang menodai putri kandungnya sendiri di daerah Depok Jawa Barat, tak ada habis-habisnya. Kasus ini sekarang sudah masuk persidangan Pengadilan Negeri Depok. Ibunda dari korban mengungkapkan selama berlangsung persidangan, keluarga suaminya selalu membawa sejumlah orang. ${ }^{9}$ Pihak terdakwa dalam proses persidangan selalu membawa gerombolan dan terkesan selalu mengintimidasi beberapa waktu lalu, sidang ada yang berusaha untuk menimbulkan gesekan cekcok mulut, yang di indikasi dari pihak terdakwa yang mepet terus ke pihak korban. Kehadiran orang-orang tersebut menimbulkan situasi tidak nyaman, terutama kepada saksi. Saksi merasa dihantui ketakutan saat mengikuti persidangan. tak hanya dirinya dan saksi yang merasa terintimidasi, bahkan tokoh masyarakat di sekitar rumah jalan rangkapan jaya. kecamatan pancoran mas, Depok, Jawa Barat. ${ }^{10}$

Pengadilan harus mampu memfasilitasi bentuk perlindungan kepada saksi korban dengan memberikan sarana ruang khusus bagi saksi korban pada saat saksi korban bersaksi di persidangan. Dengan adanya ruangan khusus untuk bersaksi, saksi korban bisa merasa lebih aman dan nyaman dalam membantu penegak hukum membongkar suatu kejahatan tanpa harus berhadapan dengan terdakwa.Urgensi perlindungan saksi korban tersebut memang harus segera dipikirkan karena pengungkapan kasus tindak pidana bergantung dari adanya bukti saksi yang membantu penegakan hukum dalam mencari kebenaran materil di persidangan, apabila tidak didukung dengan adanya perlindungan saksi korban maka mustahil pengungkapan tindak pidana dapat berjalan dengan lancar.

\section{B. Pembahasan}

\section{Perlindungan Hukum Terhadap Anak Sebagai Saksi Dalam Perkara Tindak Pidana Pemerkosaan}

Perlindungan hak anak dalam sistem peradilan pidana anak menurut Arief Gosita adalah suatu kegiatan bersama yang bertujuan untuk memulihkan keadaan dan kondisi serta kepastian hukum bagi masa depan anak. Masalah perlindungan anak menurut Arief Gosita adalah suatu fenomena yang harus disikapi dengan segera. Mengingat permasalahan anak begitu kompleks terjadi mulai dari pelecehan, kenakalan anak dan juga anak yang menjadi korban bagi predator anak hal itulah sistem perlindungan dibutuhkan untuk mencegah kejahatan serupa terulang kembali yang dapat mengancam jiwa sang anak. ${ }^{11}$

Perlindungan hukum bagi anak dalam proses peradilan lahir dari dasar pemikiran peradilan anak (juvenile justice), tujuan dari dasar pemikiran peradilan anak tidak dapat

\footnotetext{
${ }^{8}$ Ni Made Dwi Kristiani, “Kejahatan Kekerasan Seksual (Perkosaan) Ditinjau Dari Perspektif Kriminologi”, Jurnal Magister Ilmu Hukum Universitas Udayana, Denpasar, Bali, Vol.7 No.3 2014

9 https://www.suara.com/news/2015/11/27/193117/ayah-nodai-anak-kandung-ibunda-sedih-dan-terintimidasi, diakses pada Tanggal 8 Mei 2019

${ }^{10}$ Ibid.

${ }^{11}$ Nikmah Rosidah, Budaya Hukum Hakim Anak di Indonesia, Sebuah Pendekatan Hukum Progresif, , Semarang, Pustaka Magister, 2014, hlm. 47-48
} 
dilepaskan dari tujuan utamanya sendiri yakni mewujudkan kesejahteraan anak. Sebagai bagian integral dari kesejahteraan sosial. ${ }^{12}$ Saksi dalam peradilan pidana menempati posisi yang paling utama dan vital, sebagai mana terlihat dalam penempatannya dalam pasal 184 KUHP. Pada Umumnya alat bukti keterangan saksi merupakan alat bukti yang paling utama dalam perkara pidana. Dapat dikatakan tidak ada perkara pidana terlepas dari alat bukti keterangan saksi. Sekurang-kurangnya disamping alat bukti keterangan yang lain, masih selalu diperlukan pembuktian dengan alat bukti keterangan saksi. ${ }^{13}$

M Barly Ramadhany selaku Direktur Reserse Kriminal umum pada Polda Lampung menyatakan bahwa Perlindungan hak-hak saksi dan korban sudah menjadi unsur mutlak yang dilakukan Polri dalam penegakan hukum sebagaimana Undang-Undang Nomor 2 Tahun 2002 tentang Kepolisian. Dalam proses peradilan pidana dibutuhkan adanya keterangan dari seorang saksi dan/atas korban yang mendengar, melihat, mengetahui atau mengalami sendiri telah terjadinya suatu tindak pidana yang dilakukan oleh pelaku tindak pidana. Para penegak hukum dalam mencari dan menemukan kejelasan tentang tindak pidana yang dilakukan oleh pelaku tindak pidana sering kali mengalami kesulitan karena tidak dapatnya menghadirkan saksi dan/atau korban yang disebabkan karena kemungkinan adanya ancaman, baik secara fisik maupun psikis dari pihak-pihak tertentu. Apabila saksi merasa terancam jiwanya dapat mengajukan kepada pihak kepolisian apabila memungkinkan dari hasil penilaian dan kebijakan dari atasan penyidik, saksi tersebut memang dalam keadaan terancam keselamatannya sehingga perlu mendapatkan perlindungan hukum barulah saksi akan mendapatkan perlindungan dari proses penyidikan beralangsung atau bisa juga sampai selesainya proses persidangan. ${ }^{14}$

Menurut Tri Baginda Pengadilan Negeri Kota Agung menyatakan bahwa saksi dan/atau korban yang merasa dirinya berada dalam ancaman yang amat besar, maka atas persetujuan hakim saksi tersebut dapat memberikan kesaksiannya dengan atau tanpa harus hadir secara langsung pada saat berelangsung pemeriksaan perkaranya dipengadilan. Demikian pula sebagai saksi dan/atau korban dapat pula memberikan kesaksiannya dengan cara melakukan penyampaian keterangannya dengan dibuat secara tertulis yang disampaikan dihadapan pejabat yang berwenang dengan membubuhkan tanda tangannya pada berita acara yang memuat tentang isi kesaksian tersebut. ${ }^{15}$ Menurut Tri Baginda selaku Hakim Pengadilan Negeri Kota Agung mengatakan itu pula saksi dan/atau korban dapat juga didengar kesaksiannya secara langsung melalui sarana media elektronik dengan didampingi oleh pejabat yang berwenang. ${ }^{16}$

Bahwa menurut Tri Baginda selaku Hakim Pengadilan Negeri Kota Agung selama ini hakim belum menerapakan keterangan saksi secara langsung melalui sarana media elektronik, karena hakim bukan tidak mau mengoptimalkan fasilitas kesaksian melalui alat bantu elektornik berupa teleconference mengingat penggunaan media tersebut membutuhkan sinyal yang kuat, akan tetapi sinyal di daerah Tanggamus tidak memungkinkan untuk menggunakan via teleconference dalam hal ini kami menyadari bahwa hal itulah yang belum kami terapkan selama ini karena keterbatasan fasilitas dan juga sinyal di daerah Tanggamus tertutup perbukitan dan gunung-gunung jadi belum bisa dioptimalkan, oleh karea itu kami masih menggunakan cara-cara konvensional seperti menghadapkan seorang saksi kepersidangan dengan dihadiri terdakwa. ${ }^{17}$

\footnotetext{
${ }^{12}$ Ibid, hlm. 51

${ }^{13}$ M. Yahya Harahap, Pembahasan Permasalahan dan Penerapan KUHAP, Jakarta, Sinar Grafika, 2005, hlm.285

${ }^{14}$ Wawancara dengan M Barly Ramadhany selaku Direktur Reserse Kriminal umum pada Polda Lampung, Pada Tanggal 9 Mei 2019.

${ }^{15}$ Menurut Tri Baginda selaku Hakim Pengadilan Negeri Kota Agung dalam hasil wawancara Tertanggal 17 Mei 2019.

${ }^{16}$ Menurut Tri Baginda selaku Hakim Pengadilan Negeri Kota Agung dalam hasil wawancara Tertanggal 17 Mei 2019

${ }^{17}$ Menurut Tri Baginda selaku Hakim Pengadilan Negeri Kota Agung dalam hasil wawancara Tertanggal 17 Mei 2019.
} 
Fakta yang terjadi perlindungan saksi di dalam persidangan 175/Pid.Sus/2018/PN Kot Korban yang bernama Devi Yuliyanti Bin Mulyadi yang memberikan kesaksiannya dipersidangan tidak diberikan fasilitas berupa perlindungan yaitu saksi korban dipersilahkan oleh hakim dalam memberikan keterangannya dipersidangan dengan dihadiri oleh terdakwa, hal tersebut jelas akan berakibat fatal kepada psikologis korban apalagi bahwa berdasarkan laporan evaluasi psikologi an. Devi Yuliyanti Bin Mulyadi dari P2TP2A Provinsl Lampung tanggal 09 Agustus 2018 yang di buat dan ditandatangani oleh Yurni, M.Psi., psikolog dengan hasil kesimpulan memiliki gangguan psikologis:

1) Anak mengalami gangguan persepsi;

2) Anak mengalami mimpi buruk atas kejadian yang ia alami;

3) Anak takut dengan individu terutama laki-laki yang baru ia kenal;

Berdasarkan Pasal 173 KUHAP apabila menurut pendapat hakim seorang saksi itu akan merasa tertekan atau tidak bebas dalam memberikan keterangan apabila terdakwa hadir disidang maka untuk menjaga hal yang tidak diinginkan hakim dapat menyuruh terdakwa keluar untuk sementara dari persidangan selama hakim mengajukan pertanyaan kepada saksi, karena dalam Pasal 173 KUHAP juga yang memberikan kemungkinan seornag saksi bersaksi tanpa kehadiran terdakwa. ${ }^{18}$ Selain itu kejadian di Pengadilan Negeri Kota Agung dengan Putusan Nomor 77/Pid.sus/2016/PN.Kot perkara pencabulan terhadap anak di dalam persidangan terdakwa yang bernama Asnansyah dikeluarkan dari ruang sidang, hal ini sebagaimana upaya hakim untuk memberikan keleluasaan kepada saksi korban anak untuk memberikan kesaksiannya tanpa dihadiri oleh terdakwa. Dasar pertimbangan hakim tersebut sebagai bentuk perlindungan kepada saksi korban anak untuk memberikan rasa aman dan mengurangi ketakutan korban dalam memberikan keterangannya di pengadilan agar korban dapat menceritakan semua kejadiannya.

Menurut analisis peneliti bahwa apa yang sudah dilakukan oleh hakim tersebut patut diapresiasi selama ini hakim tidak proaktif dalam memberikan perlindungan khususnya bagi saksi korban, karena sangat jarang sekali perlindungan yang diberikan kepada korban di persidangan mengingat bahwa di dalam hukum acara tidak ada kewajiban bagi hakim untuk memberikan perlindungan bagi saksi dan memberikan rasa aman. Hakim memang dituntut harus proaktif di dalam persidangan karena hal tersebut adalah wilayah yuridiksinya dalam menegakan hukum dan mencari keadilan.

\section{Faktor-faktor yang Menjadi Hambatan Terhadap Perlindungan Anak Sebagai Saksi Dalam Perkara Tindak Pidana Pemerkosaan}

Faktor-faktor atau penyebab terjadinya suatu tindak perkosaan biasanya dengan posisi korban dalam hubungannya dengan pelaku, artinya korban dan pelaku sebelumnya sudah ada relasi lebih dahulu dalam ukuran intensitas tertentu antara korban dan pelaku. ${ }^{19}$ Jika dikaitkan dengan faktor yang mempengarugi penegakan hukum bahwasannya Soerjono Soekanto menggunakan tolak ukur efektivitas dalam penegakan hukum pada 5 (lima) hal, yaitu :

1) Faktor hukumnya sendiri (undang-undang);

2) Faktor penegak hukum, yakni pihak-pihak yang membentuk maupun menerapkan hukum;

3) Faktor sarana atau fasilitas yang mendukung penegakan hukum;

4) Faktor masyarakat, yakni lingkungan dimana hukum tersebut berlaku atau diterapkan;

\footnotetext{
18 Ojaruddin, “ Tinjauan Hukum Perlindungan Saksi Dan Korban Dalam Implementasi UU No. 13 Tahun 2006". Journal.Universitassuryadarma.ac.id. (2018).

19 Andika Legesan, "Korban Kejahatan Sebagai Salah Satu Faktor Terjadinya Tindak Pidana Pemerkosaan”, Jurnal Lex Crimen Vol.I No.4 Okt-Des (2012). hlm. 11
} 
5) Faktor kebudayaan, yakni sebagai hasil karya, cipta dan rasa yangdidasarkan pada karsa manusia di dalam pergaulan hidup. ${ }^{20}$

Sedangkan untuk mengetahui berhasil atau tidaknya teori Penegakan hukum menurut Lawrence Meir Friedman bergantung pada Substansi Hukum, Struktur Hukum/Pranata Hukum dan Budaya Hukum.

1) Struktur Hukum/Pranata Hukum;

2) Substansi Hukum;

3) Budaya Hukum. ${ }^{21}$

Adapun hambatan dalam mendapatkan perlindungan hukum antara lain :

1. Faktor Lembaga Perlindungan Saksi dan korban (LPSK) yang belum memiliki perwakilan di daerah dan kurangnya sosialisasi.

Menurut peneliti dari hasil kajian dan juga riset yang telah dilakukan bahwa Lembaga Perlindungan Saksi dan Korban (LPSK) masih memiliki beberapa kekurangan sehingga belum maksimal dalam menjalankan tugasnya. Diantaranya yaitu lembaga tersebut yang hanya berkedudukan di Ibu Kota Negara Republik Indonesia, dimana yang seharusnya bahwa LPSK mempunyai perwakilan di daerah sesuai dengan keperluan, karena LPSK bertanggungjawab untuk menangani pemberian perlindungan dan dan bantuan pada saksi dan korban berdasarkan tugas dan kewenangan sebagaimana diatur dalam undang-undang. ${ }^{22}$ Dengan banyaknya permasalah mengenai perlindungan saksi yang menjadi korban tindak pidana, seharusnya Pasal tersebut dapat dijadikan dasar bagi Pemerintah dalam Pasal 11 ayat (3) Undang-undang RI Nomor 13 tahun 2006 tentang Perlindungan Saksi dan Korban menyatakan membentuk yang terjadi Pasal tersebut merupakan dasar bagi Pemerintah untuk membentuk perwakilan LPSK di masing-masing daerah.

\section{Belum Diaturnya Bentuk Perlindungan Saksi di dalam KUHAP}

Menurut peneliti dari hasil kajian dan juga riset yang telah dilakukan. Berkaitan dengan tata cara pemberian perlindungan saksi, KUHAP tidak mengatur bentuk mekanisme perlindungan saksi padahal saksi adalah suatu alat bukti yang esensial yang harus diperhatikan perlindungannya mengingat saksi memiliki peran dalam membantu penegak hukum dalam menemukan kebenaran materil dalam kasus pidana, dan juga saksi juga rentan mendapatkan kerugian yang dialami ketika memberikan kesaksiannya dipersidangan, sehingga dalam hal ini saksi enggan memberikan keterangannya dipersidangan walaupun saksi mengetahui tentang terjadinya suatu peristiwa pidana. Terkait perlindungan saksi korban dan perlindungan anak berdasarkan Asas Lex specialis derogat legi generali, yaitu asas yang menafsirkna hukum yang dinyatakan bahwa hukum yang bersifat khusus mengesampingkan hukum yang bersifat umum. ${ }^{23}$ Undang-Undang Nomor 35 Tahun 2014 tentang Perubahan atas Undang-Undang Nomor 23 tahun 2002 tentang Perlindungan Anak dan Undang-undang RI Nomor 13 tahun 2006 tentang Perlindungan Saksi dan Korban belum juga mengakomodir bentuk perlindungan saksi dan perlindungan anak terhadap permasalahan yang ada dalam

\footnotetext{
${ }^{20}$ Soerjono Soekanto, Faktor-Faktor Yang Mempengaruhi Penegakan Hukum, Jakarta, PT. Raja Grafindopersada, 2008, hlm. 8.

${ }^{21}$ Endah Pertiwi, "Tanggung Jawab Notaris Akibat Pembuatan Akta Nominee Yang Mengandung Perbuatan Melawan Hukum Oleh Para Pihak". Jurnal Ius hukum dan keadilan. Vol. 2. Nomor 2, Agustus (2018).

${ }^{22}$ Riung Friko Karek, "Perlindungan Hukum Terhadap Pengungkap Fakta (Whistleblower) Berdasarkan Undang-Undang No. 13 Tahun 2006 Tentang Perlindungan Saksi dan Korban.” Jurnal Lex Administratum, Vol. IV. No. 4. April (2016). hlm. 29

${ }^{23}$ Franky Satrio Darmawan Dan Dian Adriawan Daeng Tawang, "Penerapan Asas Lex Specialis Derogat Legi Generalis Terhadap Undang-Undang Informasi Dan Transaksi Elektronik Dalam Tindak Pidana Perjudian Togel Secara Online Studi Kasus Putusan Pengadilan Negeri Jakarta Utara Nomor 599/Pid.B/2018/Pn.Jkt Utr.” Jurnal Hukum Adigama, Vol. 1. No.2 (2018).
} 
persidangan. Sebaiknya pemerintah segera memperbaharui Undang-undang Perlindungan Anak dan Undang-undang Perlindungan saksi Korban tentang bentuk perlindungan terhadap saksi anak sebagai koban yang dapat memberikan keterangannya dengan menggunakan sarana telekomunikasi berupa videocall atapun mengakui keterangan saksi tertulis kemudian dibacakan dipersidangan.

\section{Belum efektifnya Kerjasama antara Lembaga Perlindungan Saksi Dan Korban Dengan} Instansi Penegak Hukum

Menurut peneliti dari hasil kajian dan juga riset yang telah dilakukan Salah satu masalah yang terjadi adalah timbulnya ketidaksepahaman antara LPSK dengan pihak-pihak terkait yang berwenang seperti Kepolisian, Kejaksaan dan Kehakiman. karena masing-masing mempunyai egosentris tersendiri dalam melindungi saksi secara mereka adalah instrument penegak hukum tanpa adanya LPSK instansi tersebut masih bisa melindungi warga negaranya. Hal ini tentu akan menghambat tugas paling utama dari LPSK yaitu melindungi saksi dan atau korban. Seharusnya hal tersebut tidak perlu terjadi karena Pasal 18 Undangundang Nomor 11 tahun 2012 tentang Sistem Peradilan Pidana Anak telah menyebutkan bahwa Dalam menangani perkara anak, anak korban, dan/atau anak saksi, pembimbing kemasyarakatan, pekerja sosial profesional, tenaga kesejahteraan sosial, penyidik, penuntut umum, hakim, dan advokat atau pemberi bantuan hukum lainnya wajib memperhatikan kepentingan terbaik bagi anak serta mengusahakan suasana kekeluargaan tetap terpelihara. Untuk melakukan penyidikan terhadap anak penyidik juga wajib meminta pertimbangan atau saran dari pembimbing kemasyarakatan setelah tindak pidana dilaporkan atau diadukan. ${ }^{24}$

\section{Sumber Daya Manusia}

Selain LPSK, lembaga P2TP2A yang menbantu Pemerintah Daerah dalam melindungi hak-hak saksi anak sebagai korban tidak bisa memaksimalkan peranya karena jumlah personil yang terbatas dibandingkan dengan permasalahan yang ada di daerah, maka berdasarkan Peraturan Mentri Negara Pemberdayaan Perempuan dan Perlindungan Anak Nomor 5 Tahun 2010 tentang Panduan pembentukan dan Pengembangan Pusat Pelayanan Terpadu. Peraturan tersebut mengatur bahwa masing-masing daerah kabupaten/kota mempunyai kewajiban membentuk lembaga P2TP2A. ${ }^{25}$ Dimana akan lebih baik jika pemerintah dapat merekrut tenaga ahli dan pegawai khusus yang bertugas di LPSK maupun P2TP2A ataupun lembaga pemerintah lain yang fungsinya secara khusus menangani perlindungan anak,

\section{Anggaran}

Anggaran adalah salah satu hal penting yang mendukung jalannya suatu peran, yang bisa lebih memaksimalkan tujuan dan sasaran yang hendak dicapai. Salah satu faktor yang menghambat belum dibentuknya LPSK di daerah adalah anggaran yang terbatas dari Pemerintah. Akan lebih baik jika pemerintah dapat memfokuskan tambahan anggaran kepada lembaga atau institusi yang khusus menangani perlindungan saksi korban dan anak sebagai korban. Sebab hal ini akan menetukan peran bagi penegak hukum sebagai penjaga dari segala tndak kejahatan yang ada untuk mewujudkan keadilan, kepastian hukm, dan kemanfaatan. ${ }^{26}$

\footnotetext{
${ }^{24}$ Ni Made Ita Ariani, Ni Putu Rai Yuliartini, dan Dewa Gede Sudika Mangku, "Implementasi Undang-Undang Nomor 11 Tahun 2012 Tentang Sistem Peradilan Pidana Anak Terhadap Curanmor Yang Dilakukan Oleh Anak Di Kabupaten Buleleng (Studi Kasus Perkara Nomor : B/346/2016/Reskrim).” e-Journal Komunitas Yustisia Unversitas Pendidikan Ganesha Program Studi Ilmu Hukum. Vol. 2 No. 1 (2019).

25 Emy Rosnawati, "Peran Pusat Pelayanan Terpadu Pemberdayaan Perempuan Dan Anak (P2tp2a) Dalam Mengatasi Kekerasan Dalam Rumah Tangga.” Jurnal Kosmik Hukum. Vol. 18, No. 1 (2018). hlm.83.

${ }^{26}$ Clasina Mutiara Juwita Panjaitan, Ariyani Putri, "Peran Dari Lembaga Perlindungan Saksi Dan Korban (Lpsk) Dalam Pemerkosaan.” Jurnal Recidive." Vol 2, No 1 (2013) . hlm. 92.
} 
Seharusnya untuk menyikapi faktor hambatan yang demikian diatas memang diperlukan upaya kerja keras dalam memperbaiki kelemahan tersebut seperti agar dibentuknya LPSK disetiap daerah agar jangkauan perlindungannya pun merata sampai ke tingkat daerah dan juga peran penegak hukum yang harus pro aktif dan tanpa harus diminta dengan kebijakan diskresinya aparat penegak hukum dengan segera merspon perlindungan yang maksimal bagi korban demi terungkapnya kebenaran materil. Berkenaan juga dengan masalah koordinasi di setiap elemen agar selalu ditingkatkan karena untuk menunjang kinerja satu sama lain kaitannya dengan masalah perlindungan saksi korban. Bahwa tak lupa juga peran fasilitas sarana, maupun dan prasarana serta anggaran menjadi peran penting dalam mewujudkan perlindungan hukum yang baik karena jika diteliti di sektor inilah banyak upaya dan kinerja menjadi terhambat.

\section{Kesimpulan}

Berdasarkan hasil penelitian dan pembahasan tersebut di atas, maka penulis menarik kesimpulan bahwa perlindungan hukum terhadap anak sebagai saksi dalam perkara tindak pidana pemerkosaan berupa persetujuan dari hakim kepada saksi korban anak dapat memberikan kesaksiannya dengan tanpa harus hadir secara langsung saat pemeriksaan perkaranya dipengadilan, dengan menggunakan sarana telekomunikasi berupa videocall atapun mengakui keterangan saksi tertulis kemudian dibacakan dipersidangan. Bentuk perlindungan tersebut sebaiknya secara khusus diatur didalam Undang-undang Perlindungan Anak dan Undang-undang Perlindungan Saksi Korban. Sebaiknya pemerintah segera memperbaharui Undang-undang Perlindungan Anak dan Undang-undang Perlindungan saksi Korban. Selain itu Pemerintah juga segera membentuk perwakilan Lembaga Perlindungan Saksi dan Korban (LPSK) di setiap daerah dan melakukan sosialisasi kepada para penegak huukum untuk memaksimalkan bentuk perlindungan saksi korban dalam setiap proses hukum.

A. Buku

\section{Daftar Pustaka}

Harahap, M. Yahya,2005, Pembahasan Permasalahan dan Penerapan KUHAP, Jakarta, Sinar Grafika,

M Arif Mansur, Didik, Elisatris Gultom, 2006, Urgensi Perlindungan Korban Kejahatan Antara Norma dan Realita, Jakarta, Rajawali Pers.

Rosidah, Nikmah dan Rini Fatonah, 2017, Hukum Peradilan Anak, Bandar Lampung, Zam-Zam Tower.

----------, 2014, Budaya Hukum Hakim Anak di Indonesia, Sebuah Pendekatan Hukum Progresif, Semarang, Pustaka Magister.

Soekanto, Soerjono, 2008, Faktor-Faktor yang Mempengaruhi Penegakan Hukum, Jakarta, PT. Raja GrafindoPersada.

B. Jurnal

Adhyaksa, H. B.. "Implementasi Penerapan Undang-Undang Nomor 13 Tahun 2006 Tentang Perlindungan Saksi Dan Korban (Studi Di Polres Kuningan)." Jurnal Ilmu Hukum Unifikasi Develop Education and Legal Reseacrh. Vol. 2 No. 1. Januari 2015, https://journal.uniku.ac.id/index.php/unifikasi/article/viewFile/25/12.

Clasina Mutiara Juwita Panjaitan, A. P. "Peran Dari Lembaga Perlindungan Saksi Dan Korban (Lpsk) Dalam Pemerkosaan." Jurnal Recidive Vol 2, No 1 , 92. 2013, https://jurnal.uns.ac.id/recidive/article/view/32018/21390.

Intan, Eka, Putri Lembaga, Konsultan Bantuan, and Hukum Intan. "Begal Anak; Pemenuhan Hak Dan Lembaga Pembinaan Khusus Anak Kelas Ii A Bandar Lampung Fulfillment Of The Rights Of The Child In The Class Ii Special Child Coaching Institution In Bandar 
Lampung." Cepalo 2, no. 2, September 12, 2018: 45-84. https://jurnal.fh.unila.ac.id/index.php/cepalo/article/view/1764/1480.

https://doi.org/10.25041/cepalo.v2no2.1764.

Karek, R. F. "Perlindungan Hukum Terhadap Pengungkap Fakta (Whistleblower) Berdasarkan Undang-Undang No. 13 Tahun 2006 Tentang Perlindungan Saksi dan Korban." Jurnal Lex $\begin{array}{llllll}\text { Administratum, } & \text { Vol. } & \text { IV. } & \text { No. } & 4 ., & 29,\end{array}$ https://ejournal.unsrat.ac.id/index.php/administratum/article/view/11796/11388.

Kristiani, N. M. "Kejahatan Kekerasan Seksual (Perkosaan) Ditinjau Dari Perspektif Kriminologi." Jurnal Magister Ilmu Hukum Universitas Udayana, Denpasar, Bali, Vol.7 No.3. $2014 . \quad$ https://ojs.unud.ac.id/index.php/jmhu/article/view/10940/7765. https://doi.org/10.24843/JMHU.2014.v03.i03.p02.

Legesan, A. "Korban Kejahatan Sebagai Salah Satu Faktor Terjadinya Tindak Pidana Pemerkosaan." Jurnal Lex Crimen Vol.I No.4 , 11. 2012, https://ejournal.unsrat.ac.id/index.php/lexcrimen/article/view/899/714.

Mutiara Nastya Rizky, R. I. "Perlindungan Hukum Terhadap Anak Korban Eksploitasi Seksual Komersial Melalui Media Sosial." Jurnal Media Iuris Vol. 2 No. 2, Juni 2019. https://ejournal.unsrat.ac.id/index.php/lexcrimen/article/view/899/714.

Ni Made Ita Ariani, N. P. "Implementasi Undang-Undang Nomor 11 Tahun 2012 Tentang Sistem Peradilan Pidana Anak Terhadap Curanmor Yang Dilakukan Oleh Anak Di Kabupaten Buleleng (Studi Kasus Perkara Nomor : B/346/2016/Reskrim)." e-Journal Komunitas Yustisia Universitas Ganesha Program Studi Ilmu Hukum. Vol. 2, No. 2, 2019. https://ejournal.undiksha.ac.id/index.php/jatayu/article/view/23896/14492.

Nurdiana, M. A. "Tindak Pidana Pemerkosaan: Realitas Kasus Dan Penegakan Hukumnya Di Indonesia." Jurnal Fakultas Hukum Universitas Negeri Semarang (UNNES) Vol. 3. No. 1, 2019. https://jurnal.untidar.ac.id/index.php/literasihukum/article/view/1350/pdf.

Ojaruddin. "Tinjauan Hukum Perlindungan Saksi Dan Korban Dalam Implementasi UU No. 13 Tahun 2006." Journal.Universitassuryadarma.ac.id. Vol. 3, No. 2, 2013. https://journal.universitassuryadarma.ac.id/index.php/jihd/article/view/93/90. https://doi.org/10.35968/jh.v3i2.93.

Pertiwi, E. "Tanggung Jawab Notaris Akibat Pembuatan Akta Nominee Yang Mengandung Perbuatan Melawan Hukum Oleh Para Pihak." Jurnal Ius hukum dan keadilan. Vol. 2. Nomor 2, 2018. http://jurnalius.ac.id/ojs/index.php/jurnalIUS/article/view/559/pdf_79. http://dx.doi.org/10.29303/ius.v6i2.559.

Rosnawati, E. "Peran Pusat Pelayanan Terpadu Pemberdayaan Perempuan Dan Anak (P2tp2a) Dalam Mengatasi Kekerasan Dalam Rumah Tangga." Jurnal Kosmik Hukum. Vol. 18, No. 1, 2018. http://jurnalnasional.ump.ac.id/index.php/KOSMIK/article/view/2341. http://dx.doi.org/10.30595/kosmikhukum.v18i1.2341.

Silviana Anggraeni Putri, N. R. "Perlindungan Hukum Bagi Anak Korban Tindak Pidana Perdagangan Manusia Berdasarkan Undang-undang Nomor 35 Tahun 2014 yang merupakan Perubahan atas Undang-undang Nomor 23 Tahun 2002 mengenai Perlindungan Anak." $\begin{array}{lllllll}\text { Diponegoro Law Journal Vol. } & 6 . & \text { No } & 1 . & 2017 .\end{array}$ https://ejournal3.undip.ac.id/index.php/dlr/article/view/14307/13839.

Slamet, S. "Politik Hukum Pidana Dalam Kejahatan Perkosaan." Jurnal Yustisia Fakultas Hukum Universitas Sebelas Maret, Vol. 4. No. 2017. https://jurnal.uns.ac.id/yustisia/article/view/8666/7754.

Tawang, F. S. "Penerapan Asas Lex Specialis Derogat Legi Generalis Terhadap Undang-Undang Informasi Dan Transaksi Elektronik Dalam Tindak Pidana Perjudian Togel Secara Online Studi Kasus Putusan Pengadilan Negeri Jakarta Utara Nomor 599/Pid. B/2018/Pn.Jkrt Utr." Jurnal Hukum Adigama. Vol 1. No. 2018. https://journal.untar.ac.id/index.php/adigama/article/view/2844/1743. http://dx.doi.org/10.24912/adigama.v1i2.2844.

C. Undang-undang

Undang-Undang Dasar 1945 Hasil Amandemen ke 4. 
Undang-Undang Nomor 8 Tahun 1981 tentang Kitab Undang-Undang Hukum Acara Pidana.

Undang-Undang Nomor 2 Tahun 2002 tentang Kepolisian RI.

Undang-Undang Nomor 16 Tahun 2004 tentang Kejaksaan RI.

Undang-Undang Nomor 48 Tahun 2009 tentang Kekuasaan Kehakiman RI.

Undang-Undang Nomor 35 Tahun 2014 tentang Perubahan atas Undang-Undang Nomor 23 tahun 2002 tentang Perlindungan Anak.

Undang-Undang Nomor 11 Tahun 2012 tentang Sistem Peradilan Pidana Anak;

D. Internet

https://www.suara.com/news/2015/11/27/193117/ayah-nodai-anak-kandung-ibunda-sedih-danterintimidasi, diakses pada Tanggal 8 Mei 2019. 